\title{
A medialis ventrolateralis praefrontalis (orbitofrontalis) kéreg glükózmonitorozó idegsejtjei szerepet játszanak a homeosztázis fenntartásában
}

\author{
Szabó István dr., ${ }^{1,2}$ - Hormay Edina ${ }^{1,2}$ - Csetényi Bettina ${ }^{1,2}$ \\ Nagy Bernadett dr. ${ }^{1}$. Karádi Zoltán dr. ${ }^{1,2,3}$ \\ Pécsi Tudományegyetem, ${ }^{1}$ Általános Orvostudományi Kar, Élettani Intézet, ${ }^{2}$ Idegtudományi Centrum, \\ ${ }^{3}$ Szentágothai János Kutatóközpont, Molekuláris Neuroendokrinológiai Kutatócsoport, Pécs
}

\begin{abstract}
Bevezetés: A medialis orbitofrontalis kéreg fontos szerepet játszik a táplálkozás és az anyagcsere szabályozásában. Az itt található glükózmonitorozó idegsejtek e folyamatokbeli érintettsége, jellemző múködési sajátosságaik azonban még kevéssé ismertek. Célkitüzés: Kísérletsorozatunkban e kemoszenzoros idegsejtek funkcionális jelentőségét kívántuk megvilágítani. Módszer: A multibarrel mikroelektroforetikus technika segítségével elektrofiziológiai kísérleteket folytattunk, valamint a glükózmonitorozó neuronok sztreptozotocinnal való szelektív elpusztítása után anyagcserevizsgálatokat végeztünk. Eredmények: A vizsgált sejtek mintegy 15\%-a bizonyult az előagyi glükózmonitorozó ideghálózat elemének. E glükózmonitorozó és a glükózra válaszkészséget nem mutató, úgynevezett glükózinszenzitív idegsejtek eltérő neurotranszmitter- és ízérzékenységet mutattak. Akut glükóztolerancia-tesztben, a sztreptozotocinnal kezelt patkányok 30 és 60 perces vércukorértékei a kontrollállatokéinál szignifikánsan magasabbak voltak. A sztreptozotocinkezelt csoportban a plazmatriglicerid-koncentráció a kontrollokban mértnél szintén nagyobbnak bizonyult. Következtetések: Eredményeink azt igazolják, hogy a medialis orbitofrontalis kérgi glükózmonitorozó idegsejtek a belső és a külső környezet ingereinek integrációjával, az anyagcsere-folyamatok monitorozásával nélkülözhetetlenek az egészséges homeosztázis fenntartásában. Orv Hetil. 2017; 158(18): 692-700.
\end{abstract}

Kulcsszavak: praefrontalis kéreg, glükóztolerancia-teszt, trigliceridek

\section{Glucose-monitoring neurons of the medial ventrolateral prefrontal (orbitofrontal) cortex are involved in the maintenance of homeostasis}

\begin{abstract}
Introduction: The medial orbitofrontal cortex is involved in the regulation of feeding and metabolism. Little is known, however, about the role of local glucose-monitoring neurons in these processes, and our knowledge is also poor about characteristics of these cells. Aim: The functional significance of these chemosensory neurons was to be elucidated. Method: Electrophysiology, by the multibarreled microelectrophoretic technique, and metabolic investigations, after streptozotocin induced selective destruction of the chemosensory neurons, were employed. Results: Fifteen percent of the neurons responded to glucose, and these chemosensory cells displayed differential neurotransmitter and taste sensitivities. In acute glucose tolerance test, at the 30th and 60th minutes, blood glucose level in the streptozotocin-treated rats was significantly higher than that in the controls. The plasma triglyceride concentrations were also higher in the streptozotocin-treated group. Conclusions: Glucose-monitoring neurons of the medial orbitofrontal cortex integrate internal and external environmental signals, and monitor metabolic processes, thus, are indispensable to maintain the healthy homeostasis.
\end{abstract}

Keywords: prefrontal cortex, glucose tolerance test, triglycerides

Szabó I, Hormay E, Csetényi B, Nagy B, Karádi Z [Glucose-monitoring neurons of the medial ventrolateral prefrontal (orbitofrontal) cortex are involved in the maintenance of homeostasis]. Orv Hetil. 2017; 158(18): 692-700.

(Beérkezett 2017. március 20.; elfogadva: 2017. április 6.) 


\section{Rövidítések}

Ach $=$ acetil-kolin $; \mathrm{AP}=$ anteroposterior $; \mathrm{DA}=$ dopamin; GABA = gamma-aminovajsav; GIS = glükózinszenzitív; GM = glükózmonitorozó; GR = glükózreceptor; GS = glükózszenzitív; GTT = glükóztolerancia-teszt; $\mathrm{mdPFC}=$ mediodorsalis praefrontalis kéreg; $\mathrm{ML}=$ mediolateralis; $\mathrm{mOFC}=$ medialis ventrolateralis praefrontalis (orbitofrontalis) kéreg; $\mathrm{NA}=$ noradrenalin; OFC = orbitofrontalis kéreg; STZ = sztreptozotocin; $\mathrm{V}=$ ventralis; $\mathrm{VMH}=$ ventromedialis hypothalamusmag

A homeosztázis, vagyis a szervezetnek a környezethez, a változó élettéri viszonyokhoz, a különféle biológiai kihívásokhoz való alkalmazkodása során fenntartott dinamikus egyensúlyi állapot mindenkori biztosítása alapvető fontosságú az egészséges életvitel szempontjából. A megfelelő táplálék- és folyadékfelvétel, a testhőmérséklet szabályozása, és ugyanakkor például a különböző plazmametabolitok szintjének egészséges tartományban tartása is döntő jelentőségúek ennek az állandó belső egyensúlyi állapotnak a megőrzésében. A táplálkozási és anyagcsere-megbetegedések - mint az elhízás, a metabolikus szindróma, a diabetes mellitus, az anorexia és a bulimia nervosa - mind-mind a homeosztázis zavarával járó kórképek, amelyek világszerte robbanásszerüen növekvő számban fordulnak elő és a modern társadalmak egészségügyi ellátására egyre nagyobb terhet rónak. Ezért nem meglepő, hogy mára a neurofiziológiai kutatások egyik legfontosabb területe a táplálkozás és az anyagcsere központi szabályozásának vizsgálata, mivel nemcsak az ezen betegségek hátterében álló patofiziológiai elváltozások, hanem még az egészséges szervezet központi regulációs mechanizmusai sem ismertek jelenleg kellő mértékben. E tekintetben kiemelt jelentőségű a limbicus előagyban a frontalis lebeny egyik központi struktúrájára, a ventrolateralis praefrontalis (orbitofrontalis) kéregre (OFC) vonatkozó új információk nyerése.

A homloklebenyben a praefrontalis kéreg a motoros és premotoros kérgi areáktól rostralisan elhelyezkedő kéregterület, amely az előbbiekben említett neurofiziológiai kísérletek leggyakoribb alanyaiban, a rágcsálókban két fö régióra osztható: egy mediodorsalis és egy ventrolateralis területre. Ma már általánosan elfogadottan ez utóbbi agyi struktúrát feleltetjük meg az eredendően a fóemlősökben leírt, jól körülhatárolt orbitofrontalis kéregnek [1].

Ez az agyi régió a limbicus rendszer szerves részeként igen sokféle funkció szervezésében nélkülözhetetlennek tünik: meghatározza a különféle magatartási mintázatok motivációs, emocionális töltetének az érvényesülését [2], részt vesz a szociális, bizonyos szexuális és különféle adaptációs viselkedések kialakításában [3], spontán és komplex viselkedésmintázatok létrejöttében [4], valamint időlegesen tárolja a magatartási eseményekkel öszszefüggő szenzoros információkat, illetve időbeli késéssel, adekvát válaszmintákkal kapcsolja össze ezeket [5]. Régóta ismert, hogy fontos szerepet játszik a különböző szagok egymástól való elkülönítésében $[6,7]$, valamint az is, hogy az OFC, alapvető regulációs entitásként, mélyen érintett a testtömeg, a táplálék- és folyadékfelvétel, továbbá a metabolikus kontroll fenntartásában [8].

Egyes, a központi idegrendszerben található idegsejtek a glükózt nemcsak metabolizmusuk során használják fel, hanem D-glükóz hatására extracelluláris környezetük, membrántulajdonságaik átalakulása nyomán neuronalis válaszkészségük alapvetően szintén megváltozik. Ezeknek a glükózmonitorozó (GM) idegsejteknek az első leírása és részletes vizsgálatának fókuszba állítása Oomura és mtsai nevéhez füződik [9, 10]. A GM-neuronok funkcionális szempontból két csoportra oszthatók: glükózszenzitív (GS) idegsejtek, amelyek a glükóz hatására gátlódnak, és glükózreceptor (GR)-neuronok, amelyek a glükóz extracelluláris szintjének emelkedésére serkentődnek, azaz tüzelési frekvenciájukat növelik. Glükózinszenzitív (GIS) neuronoknak nevezzük azokat az idegsejteket, amelyek glükóz hatására aktivitásváltozást, válaszkészséget nem mutatnak.

GM-sejteket számos agyterületen kimutattak már: a lateralis hypothalamus areában $[9,11-16]$, a ventromedialis hypothalamusmagban $(\mathrm{VMH})[11,13,14,16$, 17], a nucleus tractus solitariiban [18-20], az area postremában $[21,22]$, az amygdalában [23-26], a globus pallidusban $[27,28]$, a nucleus accumbensben [29], valamint a praefrontalis kéregben $[13,30,31]$, és kutatócsoportunk korábban már elkezdte ezen sejtek tanulmányozását az OFC-ben is [16, 32, 33].

Az 1950-es évek végén antibiotikus hatású anyagként izolálták a sztreptozotocint (STZ) a Streptomyces achromogenes baktériumtörzsből, de igen súlyos mellékhatásai miatt ma már egyedüli indikációként csak a $\beta$-sejtekból kiinduló metasztatikus tumorok terápiájában használatos [34]. Az STZ egy D-glükózhoz hasonló szerkezetú molekula, amely szelektíven képes elpusztítani a pancreas ß-sejtjeit, ezért széles körben használják az l-es típusú diabetes mellitus állatkísérletes modelljeként [35-38]. A STZ a GLUT2-transzporteren keresztül jut be a sejtekbe, ahol szabad gyökök képzésén keresztül oxidatívstressz-folyamatokat, majd necrosist okoz [36, 3840]. A GM-idegsejtek biokémiai gépezete a $\beta$-sejtekéhez sok tekintetben hasonló, ennek megfelelően a STZ-t képesek felvenni, így annak intracerebralis adásakor a glükózmonitorozó neuronok specifikusan károsodnak, és ezen neuronok aktivitásának végleges megszünése következtében súlyos, sok tekintetben a 2-es típusú diabetes mellitushoz hasonló táplálkozási és anyagcserezavarok alakulnak ki [16, 41, 42].

$\mathrm{Az}$ OFC morfológiailag és funkcionálisan két részre tagolható: lateralis és medialis orbitofrontalis (mOFC) kéregre [43]. Vizsgálatainkban a neurofiziológiai kutatásban Oomura és mtsai által meghonosított multibarrel mikroelektroforetikus technika, továbbá a mOFC-be irányuló egyszeri kétoldali STZ-mikroinjekció segítségével, azaz a lokális GM-neuronok szelektív elpusztításával, ennek nyomán hiányuk hatásának feltárásával, ezen limbicus előagyi terület glükózmonitorozó ideg- 
sejtjeinek a múködési sajátosságait, illetve a nyert adatok révén funkcionális jelentőségüket kívánjuk megvilágítani.

\section{Módszer}

Jelen kutatásaink célja a medialis ventrolateralis praefrontalis (orbitofrontalis) kérgi glükózmonitorozó neuronok endogén és exogén kémiai érzékenységének vizsgálata, valamint a metabolikus szabályozásban betöltött szerepük tanulmányozása volt. E kísérletekben hím patkányokban a mOFC-be irányított mikroelektródával extracelluláris egysejt-tevékenységet vezettünk el mikroelektroforetikus anyagbeadások és intraoralis ízingerlések során, valamint a GM-neuronok sztreptozotocinnal való elpusztítása után glükóztolerancia-tesztet (GTT) végeztünk és megmértük több fontos metabolit plazmaszintjét. Vizsgálati módszereink részletes leírása tekintetében korábbi közleményeinkre utalunk $[31,44]$.

\section{Alanyok}

Kísérleteink során 45 felnőtt hím Wistar és SpragueDawley patkányt használtunk. A kísérleti állatok testtömege a vizsgálatok kezdetekor 250-350 g volt. A patkányszobában állandó hőmérsékletet $\left(21 \pm 2{ }^{\circ} \mathrm{C}\right)$ és páratartalmat (55-60\%) biztosítottunk. Az állatokat 12/12 órás világos/sötét ciklusban tartottuk.

\section{Mütét}

Az elektrofiziológiai vizsgálatok során a patkányok altatásához intraperitonealis injekcióval beadott uretánt $(0,6 \mathrm{ml} / 100 \mathrm{ttg}, 25 \%$ friss oldat, Sigma) alkalmaztunk. $\mathrm{Az}$ állatok fejét stereotaxiás készülékben rögzítettük. A fejbőr felvágása és a koponyacsont letisztítása után a koponyatetőn fogászati fúróval $4-5 \mathrm{~mm}$ átmérőjü lyukat fúrtunk, majd a dura bemetszése után a mikroelektródát mikromanipulátorral (MN-33, Narishige, Japán) pozicionáltuk, ezt követően hidraulikus mikrotovábbító rendszer (Narishige MO-10, Japán) segítségével vezettük le a célterületre. A vizsgált régió koordinátái Paxinos agyatlasza [45] alapján a következők voltak: anteroposterior (AP) Bregma $+3,8-4,4$, mediolateralis (ML) 0,8-1,2, ventralis (V) 3,0-3,5 mm.

A metabolikus vizsgálatokban intraperitonealisan adott ketamin (Calypsol, $50 \mathrm{mg} / \mathrm{ml}$; Richter Gedeon Nyrt., Magyarország; 0,3 ml/100 ttg) injekcióval végeztük az altatást. Az operáció a továbbiakban a mikroelektrofiziológiai kísérletekhez részben hasonló módon zajlott. Az állatok fejét stereotaxiás készülékben rögzítettük, ezután a fejbőrön hosszanti metszést ejtettünk. Miután megtisztítottuk a koponyafelszínt, fogászati fúró segítségével körülbelül 4-5 $\mathrm{mm}$ átmérőjű lyukat fúrtunk a Bregma elé. A vezetőkanült Paxinos agyatlasza [45] alapján mikromanipulátorral (MN-33, Narishige, Japán) pozicionáltuk (AP: B+4,2 mm). A rozsdamentes acélcsőból általunk készített vezetókanült (ML: 0,9 mm) a dura felszínére helyeztük, majd fogászati akriláttal a koponyához rögzítettük. A mútét végén antiszeptikus hintőport (Tetran, Richter Gedeon Nyrt., Magyarország) alkalmaztunk és kapcsokkal zártuk a sebet.

\section{Elektrofiziológiai vizsgálatok}

Az extracelluláris egysejt-tevékenység elvezetéséhez és a neurokémiai anyagok mikroelektroforetikus beadásához kutatócsoportunk által készített volfrámszálas, multibarrel üveg mikroelektródát használtunk. Az egysejt-tevékenységet a központi csőben lévő volfrámszál segítségével regisztráltuk, az azt körülvevő kilenc darab környéki kapilláriscsőbe töltöttük a mikroiontoforézissel beadandó oldatokat. Rendszerünkben az extracellulárisan felvett akciós potenciálok szûrést és erôsítést (Supertech Kft., Magyarország) követően egy analóg/digitális konverterbe (CED Micro $1401 \mathrm{mk}$ II, Cambridge Electronic Design, Cambridge, Egyesült Királyság) vezetődtek, majd a Spike2 v6.16 szoftvercsomag (Cambridge Electronic Design, Cambridge, Egyesült Királyság) segítségével történt a jelek rögzítése és elemzése.

Neurokémiai ingerlés során az elektróda környéki csöveibe különféle neuromodulátorokat, neurotranszmittereket töltöttünk, többek között D-glükózt, noradrenalint (NA), dopamint (DA), acetil-kolint (Ach) és GABA-t. Ezen oldatok idegsejtek környezetébe való juttatására mikroiontoforézis készüléket (NeuroPhore BH2, Medical Systems, Great Neck, New York, Amerikai Egyesült Államok) használtunk. Minden neurokémiai anyag hatását három különböző nagyságú, úgynevezett ejekciós áramerősséggel teszteltük.

Egysejt-tevékenység elvezetése közben megvizsgáltuk az idegsejtek ízválaszkészségét is. Ehhez a patkányok szájüregébe perforált végű polietilén csövet helyeztünk, amelyen keresztül az öt alapíznek megfelelő oldatokat fecskendeztük be két különböző koncentrációban 1-1,5 $\mathrm{ml}$ mennyiségben (1. táblázat). Komplex ízként megvizsgáltuk a narancslé hatását is. Az ízingerlést minden egyes ízoldat adása után desztillált vizes átmosás és levegö befecskendezése követte.

1. táblázat $\mid$ Az intraoralis ízingerléshez használt oldatok

\begin{tabular}{llll}
\hline Ízingerlés & Alacsony & $\begin{array}{l}\text { Magas } \\
\text { koncentráció }\end{array}$ \\
\hline Ingeroldat & Ízminőség & $0,1 \mathrm{M}$ & $0,3 \mathrm{M}$ \\
\hline Szukróz & Édes & $0,1 \mathrm{M}$ & $0,3 \mathrm{M}$ \\
$\mathrm{NaCl}$ & Sós & $0,01 \mathrm{M}$ & $0,03 \mathrm{M}$ \\
$\mathrm{HCl}$ & Savanyú & $0,001 \mathrm{M}$ & $0,003 \mathrm{M}$ \\
$\mathrm{QHCl}$ & Keserű & $0,1 \mathrm{M}$ & $0,3 \mathrm{M}$ \\
$\mathrm{MSG}$ & Umami & $10 \%$ & $25 \%$ \\
Narancslé & Komplex íz & & \\
\hline
\end{tabular}




\section{Metabolikus vizsgálatok}

Éber állatokban az előzetesen a koponyájukra rögzített vezetőkanülön keresztül bilateralis mikroinjekcióval oldalanként 7,5 $\mu \mathrm{g}$ STZ-t (Sigma S-0130, $10 \mu \mathrm{g} / \mu \mathrm{l}$ fiziológiás sóoldatban oldva) tartalmazó oldatot vagy $0,75 \mu \mathrm{l}$ fiziológiás sóoldatot juttattunk be a mOFC területére. A beadókanülök polietilén csövön keresztül 25 l-es Hamilton mikrofecskendőhöz csatlakoztak, az anyagbeadás mikroinfúziós pumpa segítségével történt (Cole-Parmer EW-74900 Multichannel Syringe Pumps, Cole-Parmer Instrument Company, Vernon Hills, Illinois, Amerikai Egyesült Államok) $0,75 \mu \mathrm{l} /$ perc sebességgel, amit további egyperces várakozás követett annak érdekében, hogy teljes legyen az oldat diffúziója a célterületen és megakadályozzuk az oldat visszaáramlását a kanülök eltávolításakor.

A szénhidrát-anyagcsere állapotát visszatükröző glükóztolerancia-teszt elvégzésére a kísérleti állatok 12 órás éheztetését követően került sor. A cukorterhelést intraperitonealisan adott 20\%-os D-glükóz-oldattal (0,2 g/ $100 \mathrm{ttg} / \mathrm{ml}$ ) végeztük két alkalommal, először az agyi mikroinjekció után 20 perccel (akut GTT), majd négy héttel később (szubakut GTT). A vérmintát az elemzéshez a patkány farokvénájából nyertük először cukorterhelés előtt, majd 9, 18, 30, 60 és 120 perccel a terhelés után. A méréseket kézi glükométerrel (Dcont IDEÁL, 77 Elektronika Kft., Magyarország) végeztük.

Az összkoleszterin, a trigliceridek és a húgysav plazmaszintjének meghatározására ugyancsak 12 órás táplálékmegvonást követően került sor. Az agyi mikroinjekció után 30 perccel farokvénából vérmintát nyertünk, amiből hidegkémiás fotométer (Spotchem EZ SP4430, Arkay, Japán) segítségével határoztuk meg a plazmametabolit-szinteket.

\section{Szövettani feldolgozás}

Vizsgálataink végeztével a kísérleti célterület pozíciójának megállapításához a kísérleti állatokat uretánnal (20\%, $8 \mathrm{ml} / \mathrm{ttkg}$ ) való túlaltatás után transcardialisan perfundáltuk, előbb fiziológiás sóoldattal, majd 4\%-os formalinnal. A mintát 4\%-os formalinban fixáltuk, az ebből készített $50 \mu \mathrm{m}$-es metszeteket 0,5\%-os krezil-violával festettük meg.

\section{Statisztikai elemzés}

Az elektrofiziológiai kísérleteink során az online és offline analízisek saját, a Spike2 v6.16 szoftverhez írt scriptek használatával történtek. Az értékeléskor azokat a változásokat tekintettük gátlásnak, illetve serkentésnek, amely esetekben a vizsgált idegsejtek tüzelési frekvenciája legalább $\pm 30 \%$-kal (vagy \pm 2 SD-vel) változott a spontán tüzelési frekvenciához képest, továbbá akkor, ha a válaszreakció intenzitásfüggőnek és ismételhetőnek bizonyult. A csoporthatások statisztikai értékelésére $\chi^{2}$-próbát alkalmaztunk az IBM SPSS Statistics 22 programcsomag használatával.

Metabolikus kísérleteink eredményeit Student-féle tpróbával a fentebb említett programcsomag segítségével elemeztük.

A különbségeket $\mathrm{p}<0,05$ esetén értékeltüik szignifikánsnak.

\section{Kisérleti engedély}

A kísérleti állatok tartása és a velük való foglalkozás során, a megfelelő engedélyek (BA02/2000; BA0104L 12; ZOHU0104L 08; BA02/2000-8/2012) birtokában a helyi, egyetemi rendelkezéseken túl, betartottuk a hazai (1998. évi XXVIII. törvény az állatok védelméről és kíméletéról; 40/2013 Kormányrendelet, 2013. II.) és a nemzetközi elóírásokat, európai uniós irányelveket (NIH Guidelines, 1997; 86/609/EEC Európa Tanácselóírás, 1986, 2006; 2010/63/EU Európa Parlamentelóírás).

\section{Eredmények}

\section{Elektrofiziológiai vizsgálatok}

Az elektrofiziológiai vizsgálatok során öt felnőtt hím Sprague-Dawley patkányban 33 idegsejt aktivitását vizsgáltuk.

Neurokémiai ingerlés során a vizsgált sejtek közül öt (15\%) változtatta meg tüzelési frekvenciáját D-glükóz iontoforetikus beadása során, vagyis ezek a sejtek az előagyi glükózmonitorozó hálózat medialis orbitofrontalis kérgi elemeinek bizonyultak (1. A ábra). NA-ra a neuronok közel negyede (23\%) változtatta meg aktivitását, míg DA-ra közel egyharmaduk (30\%) válaszolt (1. B ábra). A mOFC-ben az Ach-ra volt a legnagyobb a sejtek válaszkészsége (61\%). GABA adásakor a neuronok több mint egyharmada gátlódott (42\%) (2. táblázat).

A GM-idegsejtekról sajátos, a glükózinszenzitív neuronoktól jellemzően eltérő endogén kémiai válaszkészségük bizonyosodott be. A DA-érzékeny sejtek egyike sem volt GM, ugyanakkor a DA-ra nem érzékenyek negyede aktivitásváltozást mutatott D-glükózra. A NA esetében nem volt ilyen különbség a GM- és a GIS-sejtek érzékenysége között. Az Ach-ra nem válaszolók mindegyike GIS-neuron volt, míg az Ach-szenzitív sejtek negyede glükózmonitorozó idegsejtnek bizonyult $(\mathrm{p}<0,05)$. A GABA-ra gátlódott neuronok között közel kétszer akkora arányban voltak a GM-ók, mint a GABA-inszenzitívek között (3. táblázat).

Az öt alapízzel és a komplex ízingerként szolgáló narancslével történő gusztatoros ingerlés során a legnagyobb válaszkészséget (körülbelül 60\%) a savanyú, a keserü (1. C ábra), illetve az umami ízinger, valamint a narancslé esetében tapasztaltuk. A sejtek harmada változtatta meg tüzelési frekvenciáját a sós, míg negyedük 

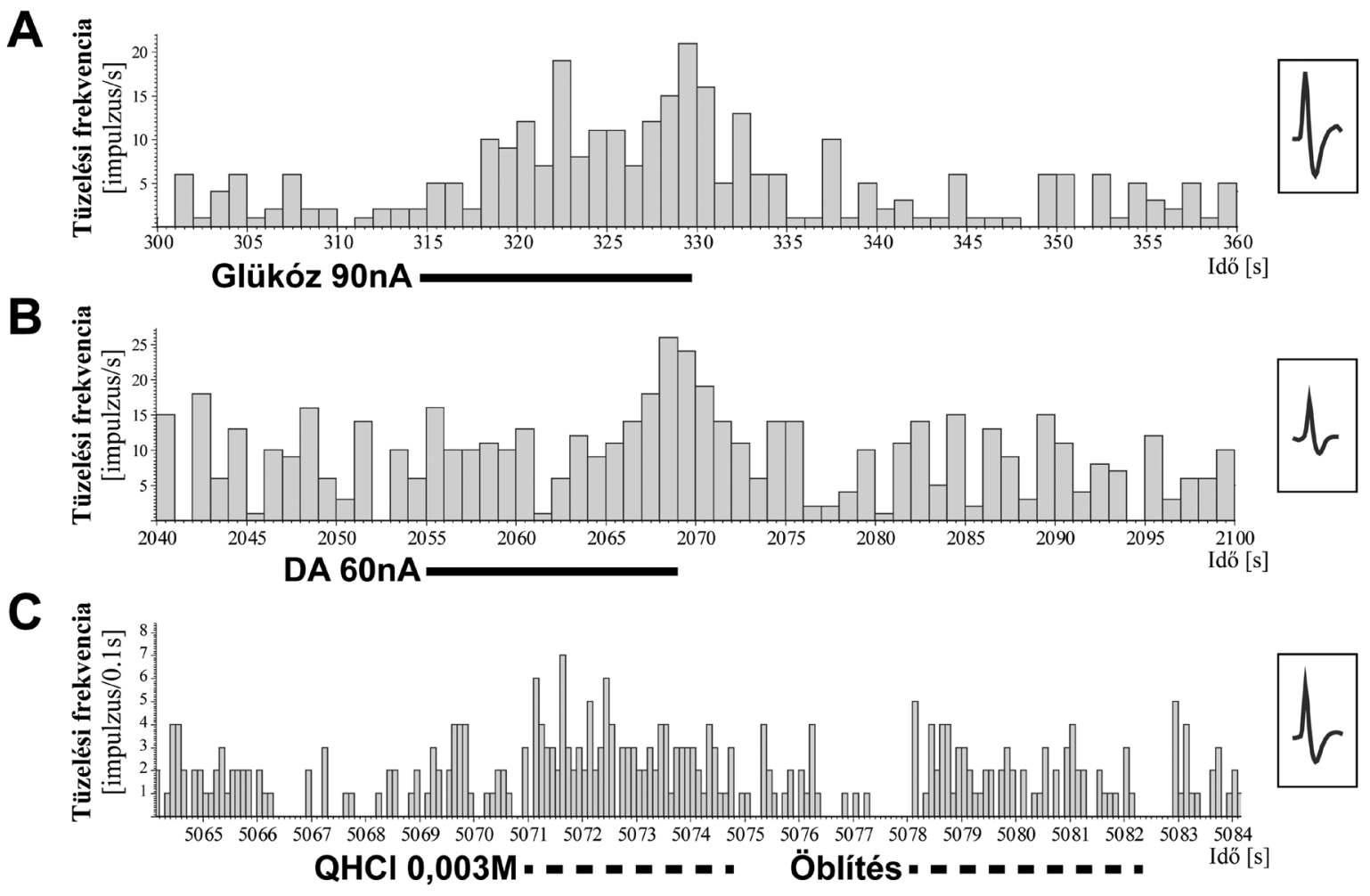$$
\text { s] }
$$

$$
\text { . }
$$

l. ábra $\quad$ Három medialis orbitofrontalis kérgi neuron endogén és exogén kémiai érzékenysége patkányban. A Glükózreceptor-neuron. B Mikroelektroforetikusan adott dopamin (DA) által kiváltott serkentődés. C Intraoralisan befecskendezett kinin-hidroklorid (keserú ízoldat) által kiváltott neuronalis serkentődés. Beágyazott képek: az adott sejtre jellemző akciós potenciál (AP)

Vastag vízszintes vonalak: a mikroelektroforetikus beadás időtartama, a számok az ejekciós áram intenzitását jelzik (nA). Vastag szaggatott vonalak: intraoralis ízingerlés időtartama. QHCl: kinin-hidroklorid. Vízszintes tengely: idő másodpercben; függóleges tengely: tüzelési frekvencia $\mathrm{AP} / \mathrm{mp}$ (A és B ábra) vagy $\mathrm{AP} / 100$ milliszekundum mértékegységben ( $\mathrm{C}$ ábra)

2. táblázat | Mikroelektroforetikusan adott D-glükóz, dopamin (DA), noradrenalin (NA), acetil-kolin (Ach) és gamma-aminovajsav (GABA) hatásai patkány medialis orbitofrontalis kérgi neuronokban

\begin{tabular}{lrl}
\hline & $+/-$ & $\varnothing$ \\
\hline Glükóz & 5 & 28 \\
DA & 9 & 24 \\
NA & 5 & 17 \\
Ach & 20 & 13 \\
GABA & 14 & 19 \\
\hline
\end{tabular}

+/- = serkentődő vagy gátlódó idegsejtek száma; $\varnothing$ = válaszkészséget nem mutató idegsejtek száma

3. táblázat | Glükózmonitorozó (GM) és glükózinszenzitív (GIS) neuronok dopamin- (DA), noradrenalin- (NA), acetil-kolin- (Ach) és gamma-aminovajsav- (GABA) érzékenysége patkány medialis orbitofrontalis kérgi neuronokban

\begin{tabular}{rrr|rr|rrrrr}
\hline & \multicolumn{2}{c|}{ DA } & \multicolumn{2}{c|}{ NA } & \multicolumn{2}{c|}{ Ach } & \multicolumn{2}{c}{ GABA } \\
\cline { 2 - 9 } & $+/-$ & $\varnothing$ & $+/-$ & $\varnothing$ & $+/-$ & $\varnothing$ & $+/-$ & $\varnothing$ \\
\hline GM & 0 & 5 & 1 & 4 & $5^{*}$ & 0 & 3 & 2 \\
GIS & 9 & 16 & 4 & 13 & 14 & 13 & 11 & 16 \\
\hline
\end{tabular}

+/- = serkentődő vagy gátlódó idegsejtek száma; * $\mathrm{p}<0,05$;

$\varnothing$ = válaszkészséget nem mutató idegsejtek száma az édes íz intraoralis befecskendezésének hatására (4. táblázat).

Mivel az ízingerlés 95\%-ban (23 sejtből 22 esetében) hatásosnak bizonyult, ízérzékenységüket tekintve a GMés a GIS-sejtek között nem találtunk szignifikáns különbséget. A tüzelési frekvenciájukat legalább egy ízingerre megváltoztató ízérzékeny neuronok több mint 10\%-a glükózmonitorozó unit volt.

4. táblázat Intraoralisan adott ízoldatok hatása patkány medialis orbitofrontalis kérgi neuronokban

\begin{tabular}{lcc}
\hline & $+/-$ & $\varnothing$ \\
\hline $\mathrm{NaCl}$ & 7 & 15 \\
$\mathrm{HCl}$ & 14 & 10 \\
$\mathrm{MSG}$ & 14 & 10 \\
Szukróz & 6 & 17 \\
QHCl & 14 & 10 \\
OJ & 15 & 9 \\
\hline
\end{tabular}

$\mathrm{NaCl}$ = sós; $\mathrm{HCl}=$ savanyú; $\mathrm{MSG}$ = umami (nátrium-glutamát); szukróz = édes; $\mathrm{QHCl}=$ keserü (kinin-hidroklorid); $\mathrm{OJ}=$ komplex ízoldat (narancslé); +/- = serkentődő vagy gátlódó idegsejtek száma; $\varnothing=$ válaszkészséget nem mutató idegsejtek száma 


\section{Glükóztolerancia-teszt}

Akut és szubakut glükóztolerancia-tesztben 12 felnőtt hím Wistar patkányt vizsgáltunk sztreptozotocin (STZcsoport, $\mathrm{n}=6$ ) vagy fiziológiás sóoldat (kontrollcsoport, $\mathrm{n}=6$ ) mOFC-beli agyi mikroinjekciója után.

Akut GTT során (20 perccel a kezelés után) a 9. és 18. percben nem mutatkozott különbség a két csoport értékei között, azonban az ezt követő időszakban a sztreptozotocinnal kezelt állatok vércukor-paraméterei változásának dinamikája eltérő, lassabban emelkedő volt, s a kontrollcsoporthoz viszonyítva a további két mérési időpontban ezeknél jóval nagyobb értékeket kaptunk (30’: $\left.\mathrm{p}<0,01 ; 60^{\prime}: \mathrm{p}<0,005\right)$. A 120. percben - bár a STZ mikroinjekciós patkányok vércukorszintje ekkor is a kontrollokénál magasabb volt - a statisztikai elemzés nem igazolt szignifikáns eltérést a két csoport között (2. ábra).

A mikroinjekciós kezeléseket követő negyedik héten végzett szubakut GTT a két csoport között nem mutatott szignifikáns különbséget.

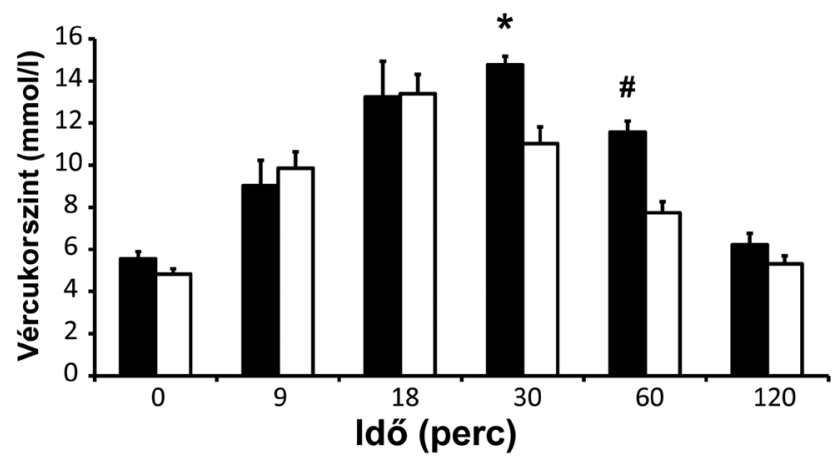

2. ábra

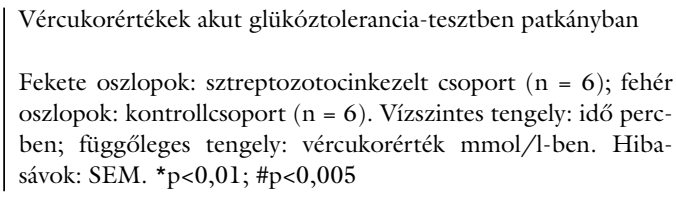

\section{Plazmametabolit-szintek}

A plazmametabolit-szinteket 28 felnőtt hím Wistar patkányban vizsgáltuk. 30 perccel a mOFC-mikroinjekciót követôen szérumösszkoleszterin-, -triglicerid- és -húgysav-meghatározást végeztünk a STZ-kezelt $(n=16)$ és a kontrollcsoportban $(n=12)$. A vizsgált metabolitok közül a koleszterin- és a húgysav-koncentrációk érdemben nem különböztek, a trigliceridek esetében viszont szignifikáns eltérés mutatkozott: a STZ-kezelés hatására a szérumtriglicerid-szint számottevően megemelkedett $(\mathrm{p}<0,005)$ (3. ábra).

\section{Megbeszélés}

Glükózmonitorozó neuronokat már számos agyi régióban azonosítottak patkányban és majomban is, az agytörzstől [19] a magasabb előagyi területeken át [15, 16,
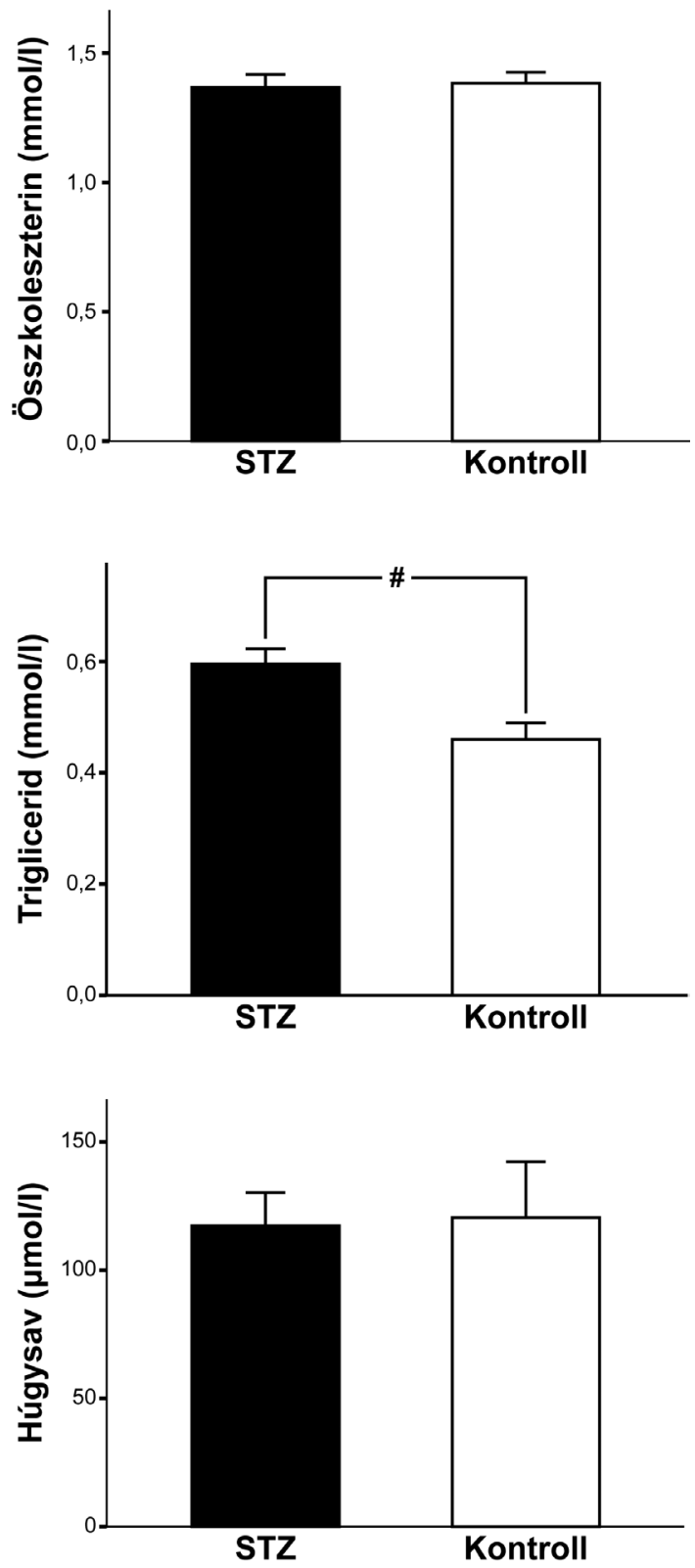

3. ábra

Összkoleszterin- (mmol/l), triglicerid- (mmol/l) és húgysav( $\mu \mathrm{mol} / \mathrm{l})$ koncentráció változásai sztreptozotocin vagy fiziológi ás sóoldat medialis orbitofrontalis kéregbe való bilateralis mik roinjekciója után patkányban

STZ = sztreptozotocinkezelt csoport $(\mathrm{n}=16)$. Kontroll: kont rollcsoport $(\mathrm{n}=12)$. Hibasávok: SEM. \#p<0,005

$29,41]$, a praefrontalis-orbitofrontalis kéregig [ $[16,31$, 41, 46, 47]. Ezen idegsejteknek nemcsak az endogén neurotranszmitterekre és neuromodulátorokra adott válaszai különböznek a glükózinszenzitív sejtekéitôl [29, $31,47]$, hanem exogén kémiai stimulusokra, így ízingerekre is eltérő módon reagálnak [31]. Ez a differenciált, a kemoszenzoros idegsejteket a GIS-unitoktól alapvetôen megkülönböztető endogén és exogén kémiai érzékenység jellemzi a ventrolateralis praefrontalis kéreg medialis régiójának GM-neuronjait is. Ezek a kemoszenzoros idegsejtek a mOFC-ben meglehetősen magas arányban 
(15\%) képviseltetik magukat, akkorában, hogy múködésük kellő erővel érvényesítheti sajátos funkcionális szerepüket e fontos limbicus kérgi struktúra regulációs folyamataiban. Adataink, korábbi, Rhesus majmok orbitofrontalis kérgében azonosított neuronokból nyert leleteinkkel együtt $[16,41]$, feltétlenül alátámasztani látszanak azt a nézetünket, amely szerint e medialis ventrolateralis praefrontalis kérgi idegsejtek, a limbicus előagyi glükózmonitorozó neuronhálózat fontos elemeiként, a belső és a külső környezet humorális szignáljainak egyidejü monitorozásával és integrációjával nélkülözhetetlen résztvevői a homeosztázis mindenkori egyensúlyát biztosító érzékeny szabályozófolyamatoknak.

Az egészséges szervezetben a központi idegrendszer fontos feladata az anyagcsere-folyamatok igen finom ellenőrzésének irányítása, amiben egyaránt szerep jut metabolikus (lebomló tápanyagok, zsírsavak, aminosavak, különféle metabolitok stb.), humorális-hormonális (inzulin, leptin, glükagon, GLP-1 stb.) és összetett idegi tényezőknek, amelyek között megtalálhatjuk nemcsak a perifériáról, hanem a különböző agyterületek specifikus kemoszenzoros neuronjaiból érkező sajátos információkat is $[16,48-50]$. Az élettani szempontból hatásos metabolizmus, ami igen szélsőséges környezeti feltételek közepette is fenntartja a homeosztázis egyensúlyát, nagyban függ a különféle perifériás jelzések megtartott centrális érzékelésétől. Ha az e feladatot ellátó specifikus kemoszenzoros neuronok múködésében bármiféle zavar lép fel, súlyos metabolikus-homeosztatikus kórállapotok alakulhatnak ki, olyanok, mint például az obesitas vagy a diabetes mellitus [16, 48].

Jelen kísérleteink bizonyítékot szolgáltattak arra vonatkozóan, hogy a ventrolateralis praefrontalis kéreg medialis régiójában található kemoszenzoros neuronok valóban fontos szerepet játszanak a metabolizmus központi szabályozásában. A szakirodalomban elsőként kimutattuk, hogy az e területre juttatott kétoldali STZmikroinjekció hatására komplex metabolikus tünetegyüttes jön létre: GTT során kóros glükóztoleranciaeltérést, továbbá a metabolitmérésekben emelkedett plazmatriglicerid-koncentrációt állapítottunk meg. Ezen elváltozások együttes jelenléte megerősíti a kórállapot komplex metabolikus betegségnek megfelelő súlyos megítélését, amit az is alátámaszt, hogy magas plazmatriglicerid-szint - a többi között - jellemzően diabetes mellitusban és elhízásban fordulhat elő. Mind a szénhidrát-, mind pedig a zsíranyagcsere zavarai más előagyi struktúrák (VMH, mdPFC) esetében is a sztreptozotocinkezelés szokásos következményei voltak [16, 44]. $\mathrm{Az}$ eddigiek alapján általánosságban szintén érvényes igazságként kell leszögeznünk, hogy különböző agyterületeken a GM-idegsejtek sztreptozotocinnal való elpusztítása sajátos táplálkozási és anyagcserezavarok kialakulásához vezet $[16,41,42,51]$.

A táplálkozási és anyagcsere-betegségek egyre nagyobb, rohamosan növekvő terhet rónak a modern tár- sadalmakra. E kórformák eredményes gyógyítása ma még teljességgel megoldatlan, s e tényt korunk orvostudományának legsúlyosabb problémái között tartjuk számon. A gyógyítás eredménytelensége, meggyőződésünk szerint, elsősorban abból ered, hogy a terápiás próbálkozások a perifériás patológiát célozzák, s figyelmen kívül hagyják a fentiekben tárgyalt központi idegrendszeri zavarokat, amelyek e betegségek hátterében ugyanakkor kóroki szerepet játszhatnak. A jelen kísérleti eredményeink, korábbi adatainkkal együtt, rávilágítottak a központi GM-ideghálózat kemoszenzoros neuronjainak e kórfolyamatok létrejöttében és fenntartásában nyilvánvaló érintettségére. Számunkra egyértelműnek tünik, hogy a glükózmonitorozó idegsejtek megtartott fiziológiás múködése elengedhetetlen feltétele a homeosztázis egyensúlya megőrzésének. Mindezeket figyelembe véve remélhető, hogy e kemoszenzoros neuronok sokrétú múködési sajátosságainak, funkcionális jelentőségének jobb megértése új gyógyszertargetek azonosítását, hatékony, új terápiás stratégiák kidolgozását eredményezheti.

Anyagi támogatás: Ajinomoto 51064/2009; PTE AOK KA 2013/34039/1; EFOP-3.6.1-16-2016-00004.

Szerzői munkamegosztás: Sz. I.: A kísérletek megtervezése és lefolytatása, az adatok feldolgozása és statisztikai elemzése, a kézirat megírása. H. E., Cs. B., N. B.: A kísérletek lefolytatása, az eredmények megbeszélése. K. Z.: A hipotézisek kidolgozása, a kísérletek megtervezése és vezetése, a kézirat megszövegezése. A cikk végleges változatát valamennyi szerző elolvasta és jóváhagyta.

Érdekeltségek: A szerzőknek nincsenek érdekeltségeik.

\section{Köszönetnyilvánítás}

Kiemelt köszönet illeti Fuchs Ildikó szakasszisztenst a kísérletek megszervezésében és kivitelezésében nyújtott értékes segítségéért, valamint Kovácsné Korona Erzsébet laboratóriumi asszisztenst a kísérleti állatok agyának szövettani feldolgozásáért.

\section{Irodalom}

[1] Brodmann, K.: Vergleichende Lokalisationslehre der Grosshirnrinde: in ihren Prinzipien dargestellt auf Grund des Zellenbaues. Barth Verlag, Leipzig, 1909.

[2] Kringelbach, M. L., Rolls, E. T.: The functional neuroanatomy of the human orbitofrontal cortex: evidence from neuroimaging and neuropsychology. Prog. Neurobiol., 2004, 72, 341-372.

[3] Nonneman, A. J., Kolb, B. E.: Lesions of hippocampus or prefrontal cortex alter species-typical behaviors in the cat. Behav. Biol., 1974, 12, 41-54.

[4] Kolb, B.: Animal models for human PFC-related disorders. Prog. Brain Res., 1990, 85, 501-519.

[5] Freedman, M., Oscar-Berman, M.: Bilateral frontal lobe disease and selective delayed response deficits in humans. Behav. Neurosci., 1986, 100, 337-342.

[6] Tanabe, T., Yarita, H., Iino, M., et al.: An olfactory projection area in orbitofrontal cortex of the monkey. J. Neurophysiol., $1975,38,1269-1283$. 
[7] Eichenbaum, H., Shedlack, K. J., Eckmann, K. W.: Thalamocortical mechanisms in odor-guided behavior. I. Effects of lesions of the mediodorsal thalamic nucleus and frontal cortex on olfactory discrimination in the rat. Brain Behav. Evol., 1980, 17, 255-275.

[8] Kolb, B.: Functions of the frontal cortex of the rat: a comparative review. Brain Res., 1984, 320, 65-98.

[9] Oomura, ., Ono, T., Ooyama, H., et al.: Glucose and osmosensitive neurones of the rat hypothalamus. Nature, 1969, 222, 282 284.

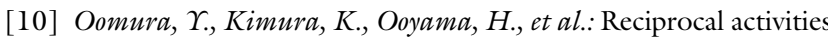
of the ventromedial and lateral hypothalamic areas of cats. Science, 1964, 143, 484-485.

[11] Oomura, Y.: Input-output organization of the hypothalamus relating to food intake behavior. In: Morgane, P. J., Panksepp, J. (eds.): Handbook of the hypothalamus. M. Dekker, New York, 1980, 557-620

[12] Aou, S., Oomura, Y., Lenard, L., et al.: Behavioral significance of monkey hypothalamic glucose-sensitive neurons. Brain Res., $1984,302,69-74$.

[13] Oomura, $\Upsilon$, Yoshimatsu, H.: Neural network of glucose monitoring system. J. Auton. Nerv. Syst., 1984, 10, 359-372.

[14] Oomura, $\Upsilon$.: Chemical and neuronal control of feeding motivation. Physiol. Behav., 1988, 44, 555-560.

[15] Karadi, Z., Faludi, B., Hernadi, I., et al.: Role of forebrain glucose-monitoring neurons in the central control of feeding: II. Complex functional attributes. Neurobiology (Bp.), 1995, 3, 241-256.

[16] Karadi, Z., Lukats, B., Papp, S., et al.: The central glucose-monitoring neural network: major protector of the adaptive homeostatic balance for well being of the organism. International Congress Series, 2004, 1269, 30-33.

[17] Minami, T., Oomura, Y., Sugimori, M.: Electrophysiological properties and glucose responsiveness of guinea-pig ventromedial hypothalamic neurones in vitro. J. Physiol., 1986, 380, 127143.

[18] Adachi, A., Kobashi, M., Funahashi, M.: Glucose-responsive neurons in the brainstem. Obes. Res., 1995, 3(Suppl. 5), 735S740 s.

[19] Adachi, A., Shimizu, N., Oomura, Y., et al.: Convergence of hepatoportal glucose-sensitive afferent signals to glucose-sensitive units within the nucleus of the solitary tract. Neurosci. Lett., $1984,46,215-218$

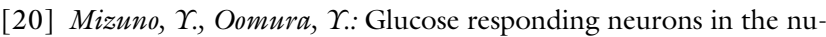
cleus tractus solitarius of the rat: in vitro study. Brain Res., 1984, 307, 109-116.

[21] Adachi, A., Kobashi, M.: Convergence of hepatic gluco- and osmosensitive inputs on chemosensitive units in the medulla oblongata of rat. In: Oomura, Y. (ed.): Emotions: neural and chemical control. Japan Scientific Societies Press, Tokyo, 1986, $103-113$

[22] Adachi, A., Kobashi, M., Miyoshi, N., et al.: Chemosensitive neurons in the area postrema of the rat and their possible functions. Brain Res. Bull., 1991, 26, 137-140.

[23] Karadi, Z., Oomura, ., Nishino, H., et al.: Lateral hypothalamic and amygdaloid neuronal responses to chemical stimuli in the rhesus monkey. In: Morita, H. (ed.): Proceedings of the 22nd Japanese Symposium on Taste and Smell. Asahi University Press, Gifu, 1988, 121-124.

[24] Nakano, Y., Lenard, L., Oomura, Y., et al.: Functional involvement of catecholamines in reward-related neuronal activity of the monkey amygdala. J. Neurophysiol., 1987, 57, 72-91.

[25] Nakano, Y., Oomura, Y., Lenard, L., et al.: Feeding-related activity of glucose- and morphine-sensitive neurons in the monkey amygdala. Brain Res., 1986, 399, 167-172.

[26] Karadi, Z., Scott, T. R., Oomura, Y., et al.: Complex functional attributes of amygdaloid gustatory neurons in the rhesus monkey. Ann. N.Y. Acad. Sci., 1998, 855, 488-492.
[27] Karadi, Z., Faludi, B., Lenard, L., et al.: Glucose-sensitive neurons of the globus pallidus: II. Complex functional attributes. Brain Res. Bull., 1995, 37, 157-162.

[28] Lenard, L., Karadi, Z., Faludi, B., et al.: Glucose-sensitive neurons of the globus pallidus: I. Neurochemical characteristics. Brain Res. Bull., 1995, 37, 149-155.

[29] Papp, S., Lukats, B., Takacs, G., et al.: Glucose-monitoring neurons in the nucleus accumbens. Neuroreport, 2007, 18, 15611565 .

[30] Nagy, B., Takacs, G., Szabo, I., et al.: Taste reactivity alterations after streptozotocin microinjection into the mediodorsal prefrontal cortex. Behav. Brain Res., 2012, 234, 228-232.

[31] Nagy, B., Szabo, I., Papp, S., et al.: Glucose-monitoring neurons in the mediodorsal prefrontal cortex. Brain Res., 2012, 1444, $38-44$.

[32] Karadi, Z., Varju, G., Hernadi, I., et al.: Functional heterogenity of orbitofrontal neurons in the rat and rhesus monkey. Neurobiology, 1997, 5, 159.

[33] Karadi, Z., Egyed, R., Hernadi, I., et al.: Integrative processing of endogenous and exogenous chemical signals by glucose-monitoring neurons of the primate orbitofrontal cortex. Appetite, $1998,31,263$

[34] Murray-Lyon, I. M., Eddleston, A. L., Williams, R., et al.: Treatment of multiple-hormone-producing malignant islet-cell tumour with streptozotocin. Lancet, 1968, 2, 895-898.

[35] Ganda, O. P., Rossini, A. A., Like, A. A.: Studies on streptozotocin diabetes. Diabetes, 1976, 25, 595-603.

[36] Szkudelski, T.: The mechanism of alloxan and streptozotocin action in B cells of the rat pancreas. Physiol. Res., 2001, 50, 537546.

[37] Garvey, W. T., Huecksteadt, T. P., Birnbaum, M. J.: Pretranslational suppression of an insulin-responsive glucose transporter in rats with diabetes mellitus. Science, 1989, 245, 60-63.

[38] Like, A. A., Rossini, A. A.: Streptozotocin-induced pancreatic insulitis: new model of diabetes mellitus. Science, 1976, 193, 415417.

[39] Kadowaki, T., Kasuga, M., Akanuma, Y., et al.: Decreased autophosphorylation of the insulin receptor-kinase in streptozotocin-diabetic rats. J. Biol. Chem., 1984, 259, 14208-14216.

[40] Rakieten, N., Rakieten, M. L., Nadkarni, M. R.: Studies on the diabetogenic action of streptozotocin (NSC-37917). Cancer Chemother. Rep., 1963, 29, 91-98.

[41] Karadi, Z., Lukats, B., Papp, S., et al.: Involvement of forebrain glucose-monitoring neurons in taste information processing: electrophysiological and behavioral studies. Chem. Senses, 2005, 30(Suppl. 1), i68-i69.

[42] Keszthelyi, Z., Past, T., Lukats, B., et al.: The central effect of chromium on glucose metabolism. Pharmacopsychiatry, 2004, $37,242$.

[43] Elliott, R., Dolan, R. J., Frith, C. D.: Dissociable functions in the medial and lateral orbitofrontal cortex: evidence from human neuroimaging studies. Cereb. Cortex, 2000, 10, 308-317.

[44] Nagy, B., Szabo, I., Takacs, G., et al.: Impaired glucose tolerance after streptozotocin microinjection into the mediodorsal prefrontal cortex of the rat. Physiol. Internatl., 2016, 103, 403-412.

[45] Paxinos, G. W.: The rat brain in stereotaxic coordinates. Academic Press, Inc., 1997.

[46] Lukats, B., Inoue, T., Mizuno, M., et al.: Electrophysiological and behavioral evidences of the feeding-related neuronal processes in the orbitofrontal cortex. International Congress Series, 2007, 1301, 230-233.

[47] Nagy, B., Szabo, I., Csetenyi, B., et al.: Noradrenaline and acetylcholine responsiveness of glucose-monitoring and glucose-insensitive neurons in the mediodorsal prefrontal cortex. Brain Res., 2014, 1543, 159-164.

[48] Levin, B. E.: Metabolic sensing neurons and the control of energy homeostasis. Physiol. Behav., 2006, 89, 486-489. 
[49] Pannacciulli, N., Le, D. S, Salbe, A. D., et al.: Postprandial glucagon-like peptide-1 (GLP-1) response is positively associated with changes in neuronal activity of brain areas implicated in satiety and food intake regulation in humans. Neuroimage, 2007, 35, 511-517.

[50] Rocca, A. S., Brubaker, P. L.: Role of the vagus nerve in mediating proximal nutrient-induced glucagon-like peptide-l secretion. Endocrinology, 1999, 140, 1687-1694.
[51] Egyed, R., Lukats, B., Karadi, Z.: Diabetes mellitus-like metabolic deficits elicited by ventromedial hypothalamic streptozotocin microinjection. J. Physiol. (Lond.), 2000, 526, 173-174.

(Karádi Zoltán dr., Pécs, Szigeti út 12., 7624 e-mail: zoltan.karadi@aok.pte.hu)

Új fejlesztés az egészségügyben dolgozók, tanulók részére!

A magyar nyelvứ szakirodalmi keresőszolgáltatás

\section{Mi a NOTA? \\ Napivizit Orvosi Tudástár Alkalmazás}

Mit tud a NOTA portál?

Megkönnyíti a magyar nyelvü szakirodalmi források keresését.

Eszköztől függetlenül, akár okostelefonról, a betegágy mellett állva is használható.

\section{Miben kereshet a NOTA-val?}

Az Akadémiai Kiadó folyóirataiban: Orvosi Hetilap, Magyar Sebészet, Mentálhigiéné és Pszichoszomatika.

Más kiadók magyar nyelvü

szakfolyóirataiban: pl. Lege Artis

Medicinae, Hypertonia és Nephrologia Ideggyógyászati Szemle.

A hatályos szakmai irányelvekben.

Magyar nyelvű kérdésekre adott angol nyelvű találatokban, a PubMeden.

\section{nota.hu}

Amennyiben további információra lenne szüksége, keressen minket elérhetőségeinken: journals@akademiai.hu /hirdetes@akademiai.hu

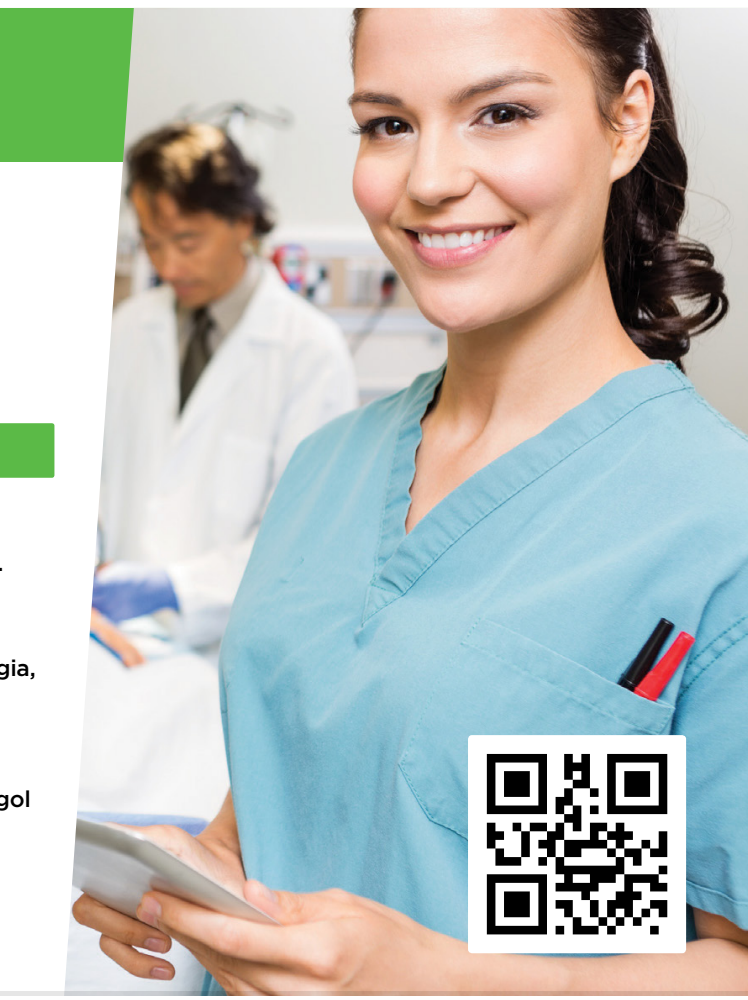

Akadémiai Kiadó

A Wolters Kluwer Csoport tagja

1117 Budapest, Prielle Kornélia u. 21-35. / Telefon: (1) 464-8246

www.akademiai.hu / www.akademiai.com
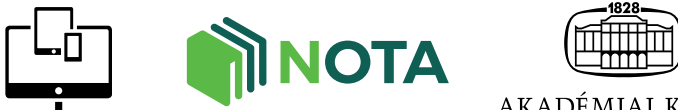

AKADÉMIAI KIADÓ 